\title{
Numbers Through the Ages
}

\author{
Edited by \\ Graham Flegg \\ Reader in the History of Mathematics \\ Open University
}

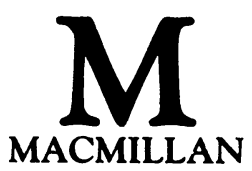

in association with

The Open University

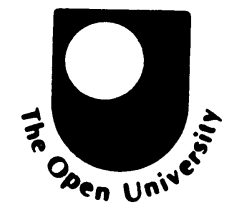


(C) The Open University 1989

All rights reserved. No reproduction, copy or transmission of this publication may be made without written permission.

No paragraph of this publication may be reproduced, copied or transmitted save with written permission or in accordance with the provisions of the Copyright Act 1956 (as amended), or under the terms of any licence permitting limited copying issued by the Copyright Licensing Agency, 33-4 Alfred Place, London WC1E 7DP.

Any person who does any unauthorised act in relation to this publication may be liable to criminal prosecution and civil claims for damages.

First published 1989

Published by

MACMILLAN EDUCATION LTD

Houndmills, Basingstoke, Hampshire RG21 2XS

and London

in association with

THE OPEN UNIVERSITY

Walton Hall

Milton Keynes MK7 6AA

Distributed in the USA by

Sheridan House Inc.

145 Palisade Street

Dobbs Ferry

NY10522

Typeset by Footnote Graphics,

Warminster

British Library Cataloguing in Publication Data

Numbers through the ages.

1. Number system \& numeration. Origins

I. Flegg, Graham, 1924-

$513^{\prime} .5$

ISBN 978-0-333-49131-7

ISBN 978-1-349-20177-8 (eBook)

DOI 10.1007/978-1-349-20177-8 


\section{Contents}

Acknowledgements

Preface vii

1 Introduction 1

2 Counting systems 5

Decimal counting 5

$\begin{array}{ll}\text { Primitive counting methods } & 7\end{array}$

Remnants of ancient counting $\quad 30$

Finger and body counting $\quad 33$

Tallies and knots $\quad 37$

The origin of counting $\quad 55$

3 Number words $\quad 56$

Linguistic principles $\quad 56$

$\begin{array}{ll}\text { Adjectives and the dual } & 57\end{array}$

$\begin{array}{ll}\text { Reconstruction of original Indo-European words } & 61\end{array}$

The origins of 'ten', 'hundred', 'thousand' and 'million' 68

Remnants of non-decimal number words $\quad 74$

4 Written numbers $\quad 76$

$\begin{array}{ll}\text { Egyptian numerals } & 76\end{array}$

$\begin{array}{lr}\text { Sumerian and Babylonian numerals } & 80\end{array}$

$\begin{array}{lr}\text { Chinese numerals } & 84\end{array}$

Greek numerals and their derivatives $\quad 88$

$\begin{array}{lr}\text { Roman numerals } & 98\end{array}$

$\begin{array}{lr}\text { Mayan numerals } & 100\end{array}$

$\begin{array}{ll}\text { Early Hindu numerals } & 102\end{array}$

$\begin{array}{ll}\text { The introduction of place-value in India } & 106\end{array}$

Hindu numerals and the Arabs $\quad 112$

$\begin{array}{ll}\text { Hindu-Arabic numerals in the West } & 116\end{array}$

5 Fractions and calculation $\quad 131$

$\begin{array}{ll}\text { Natural and unit fractions } & 131\end{array}$

$\begin{array}{ll}\text { Egyptian calculation with fractions } & 133\end{array}$

Babylonian sexagesimal fractions and algebra $\quad 144$

$\begin{array}{ll}\text { Sexagesimal fractions and astronomy } & 156\end{array}$

Fractions in Ancient Greece, China and India 158

$\begin{array}{ll}\text { Decimal fractions in China and among the Arabs } & 170\end{array}$

$\begin{array}{ll}\text { Decimal fractions in Western Europe } & 172\end{array}$ 
6 Aids to calculation $\quad 176$

$\begin{array}{ll}\text { The abacus in antiquity } & 176\end{array}$

$\begin{array}{lr}\text { The monastic abacus } & 181\end{array}$

$\begin{array}{ll}\text { Calculation on the lines } & 184\end{array}$

The Chinese, Japanese and Russian abaci $\quad 190$

$\begin{array}{ll}\text { Early calculating machines } & 196\end{array}$

$\begin{array}{lr}\text { The automatic computer } & 198\end{array}$

$\begin{array}{ll}\text { Conclusions } & 214\end{array}$

$\begin{array}{lc}\text { References and notes } & \mathbf{2 1 6}\end{array}$

$\begin{array}{lr}\text { Bibliography } & \mathbf{2 2 0}\end{array}$

$\begin{array}{ll}\text { Index } & \mathbf{2 2 1}\end{array}$ 


\section{Acknowledgements}

The author and publishers wish to thank the following who have kindly given permission for the use of copyright material: Bibliothèque Nationale, Paris, for the reproductions of an abacus of the Gerbert School, Latin 8663, Fol. 49, and a Roman hand abacus, Cabinet des Médailles; The British Library for the reproductions of finger numbers from a thirteenth-century Spanish codex, in Lucia Paccioli's Summa de arithmetica, geometria proportioni et proportionalita, 1494, and the first page of Crafte of Nombrynge; The British Museum for reproductions of part of a Babylonian clay tablet, Mayan day and month signs, Mayan numbers on stone fragment found in British Honduras, extract from the Rhind Papyrus, and an extract from the Mathematical Leather Roll; Cambridge University Press for illustrations from Science and Civilisation in China Vol. 3 by J. Needham, 1970; Dover Publications for an illustration from A Source Book in Mathematics Vol. 1 by D. E. Smith, 1959; Ferranti International for photograph of Mk. 1 computer, ref. no. G869, 1950; Fototeca Unione for a reproduction of the inscription on the Colonna rostrata, No. 1324; Hessische Landes-und-Hochschul Bibliothek, Darmstadt for an extract from the Carmen de algorismo of Alexandre de Villa Dei, 2640, Nr. 15 , folio $204^{r}$; History of Science Society for material from 'Fundamental Steps in the Development of Numeration' by Carl B. Boyer, Isis, 1944, 35, pp. 153-68; IBM UK Ltd for illustrations of the Jacquard loom and the IBM Automatic Sequence Controlled Calculator; Institut Royal du Patrimoine Artistique, Brussels, for a schematic drawing of the Ishango bone; Linden-Museum Stuttgart for the reproduction of a Philippine sword, Luzon, Inv. No. 35 311; The MIT Press for material from Number Words and Number Symbols by K. Menninger, 1969; National Museum of Finland for the reproduction of a Finnish tally stick; National Museum of Ireland for the reproduction of an Irish gravestone from Aglish with Ogham characters; Österreiche Nationalbibliothek, Vienna, for an extract from a twelfth-century German manuscript on algorism, Codex 275; Raetisches Museum, Chur, for the reproduction of two 'milk sticks', XI 402 and H 1972.345; Royal Astronomical Society for the reproduction of a woodcut from Reisch, Magarita philosophica, 1508, showing Pythagoras using an abacus; Trustees of the Science Museum for reproductions of a Chinese suan pan, Russian ščët, two views of Pascal's calculating machine and Leibniz's calculating machine, calculator by $\mathrm{C}$. Thomas, Babbage's difference engine, Scheutz's difference machine, Hollerith horizontal sorting machine and Babbage's operation card; Society of Antiquaries of London for the reproduction of British exchequer tallies; Springer Verlag GmbH for material from 'The Ritual Origin of Counting', A. Seidenberg in Archive for History of Exact Sciences, 1962; Staatliche Museen zu Berlin for reproduction of the Sumerian clay tablet, VAT 12593; TAP Service, Athens, for reproduction of a Salamis tablet; Vandenhoeck and Ruprecht for the reproduction of an alpscheit, Japanese soroban and diagram showing the stages of use of a soroban, bundle of 
Alpine number billets, a number stick of split bamboo and capital tesserae; and with MIT Press for reproductions of a Chinese bank draft, Chinese commercial price tag and Chinese numeral; Yale University, Sterling Memorial Library, for the reproduction of cuneiform text, Babylonian Collection, YBC 7289.

Every effort has been made to trace all the copyright holders but if any have been inadvertently overlooked the publishers will be pleased to make the necessary arrangement at the first opportunity. 


\section{Preface}

The material of this book originally formed part of the Open University course AM289 History of Mathematics.

One fundamental aspect of the history of mathematics deals with the evolution of the concept of number, with the representation of numbers by words and symbols, and with the basic methods of calculation which have developed from ancient times to the present day. This aspect is of considerable general interest, and is accessible to the general reader including people who are not mathematically inclined. Since the Open University course was designed for a wide spectrum of students, the topic of 'number' was chosen as a special area of study suitable for non-mathematicians taking the course as an alternative to the calculus - an area of historical study requiring considerable mathematical experience.

The original course units which have been edited to form the present work were written by Professor B. L. van der Waerden, Dr Menso Folkerts, Dr E. Neuenschwander, Dr S. H. Hollingdale, and the present Editor, who was also chairman and principal author of the course, and was responsible for the academic editing of the material written by other authors. The units were as follows:

N1 Counting I: Primitive and More Developed Counting Systems (van der Waerden and Flegg)

N2 Counting II: Decimal Number Words, Tallies, and Knots (van der Waerden and Flegg)

N3 Written Numbers (van der Waerden and Folkerts)

N4 Written Fractions (van der Waerden)

N5 Methods of Calculation (van der Waerden and Neuenschwander)

11 Mathematics and Man - four sections from Part A (Hollingdale).

The material from Unit 11 was not part of the 'numbers' option.

In the course of the present editing, exercises and specimen answers have been deleted or have been incorporated into the main text. Statements of objectives and a number of inessential illustrations have also been removed. In some cases the order of presentation has been changed, and in a few instances additional material has been provided by the Editor for completeness or to reflect aspects of recent research.

AM 289 History of Mathematics was successfully presented by the Open University for ten years, the final year of presentation being 1985 . Since that year there have been many requests received to have aspects of the course made once again available. In presenting this present work it is very much hoped that such requests may be, at least to a significant extent, adequately met. 
Particular thanks are due to Professor van der Waerden for his co-operation in the preparation of the original 'numbers' units, and also for readily agreeing to the re-editing of his material to form this book.

The Open University

GRAHAM FLEGG

June 1988 